\title{
Conclusion: Civic Security
}

\section{VICKI LUKER}

This book's overriding aim is to advance the goal of 'civic security'. Joan's story that was reproduced at the beginning indicated some of the term's meanings in reverse. An abused and ostracised woman with HIV, civic security was lacking from her life and death. Within the terms of this volume her experience was one result of the vicious circle produced conjointly by HIV and the complex factors that come under the rubric 'law and order' - and contributors have outlined others. Because the introduction and first chapter argued that civic security would offer both some immunity to such harms and a means of facilitating virtuous circles, this conclusion returns to the case for 'civic security' while flagging some big difficulties that do not, however, negate the general thrust.

Civic security, as earlier discussed (see Luker and Dinnen this volume, chapter one) in one narrow but influential sense refers to the security of person that states in the Western democratic pattern nominally guarantee their citizens. But if 'citizenship' is used more loosely for 'membership' of a political communitylocal, national, global, or whatever - civic security can designate that safety and regard granted to an individual by virtue of his or her inalienable 'belonging' to that group.

The governance of civic security - where 'governance' refers to the institutions, processes, and values that regulate social life - in most nations involves disparate actors. In PNG the role in this played by a young state is important and necessary, even if less effective than it could be within its limits; but in most parts of PNG and for most people, the state's role is small, if not absent. Hence for most citizens this task will de facto remain largely the activity of the communities, however configured, where they live. The governance of civic security thus falls within two often tenuously related domains: that of the state, and that of community. The connections between local and national governance are thin, like the waist of an hourglass; and the institutions that link them at this juncture-police, schools, aid-posts, village courts - are stressed.

Several chapters in this volume address HIV and 'law and order' through a focus on state law and the state's law and justice sector. PNG's state, its laws, its agencies, can be more visible to the international community, and better 
connected to it by flows of information, symbols, personnel and money than it is visible or connected to most of its citizens. This is perhaps most painfully demonstrated with respect to state law. Former Australian High Court judge and human rights advocate Michael Kirby has quipped that shortly after HIV was identified, so was the problem of internationally epidemic HIL: highly ineffective laws (Kirby 2009, 5). Certainly law reform can have irresistible justification, many benefits incidental to its primary purpose, and in some circumstances a change of law does lead promptly to changes in practice: but, as contributors note here, in PNG law reform is only the first step, and hard though that step may be, the further steps that would make new law effective can be even harder and also dependent on favourable terrain (Fletcher and Gonapa this volume; Stewart this volume). In the year 2010, as this book goes to press, law reform relating to sorcery, sex work and homosexuality is likely to be debated in some fora in PNG (Anon. 2009a; Anon. 2009b; Papik 2010) and the long-anticipated Lukautim Pikinini (Child) Act 2009, including provisions for children infected or affected by HIV is due to be gazetted (Aggleton et al 2009, 14; HELP 2005, 103-104). But PNG's experience so far with the HIV/AIDS Management and Prevention (HAMP) Act cautions against expectations of great impact on the ground. Although the HAMP Act is the best HIV legislation in the Pacific and intensely appreciated in some informed (and many transnational) circles, too few people in PNG know or care about it, and those who do have too few resources to implement it (CAP 2009, 56; Aggleton et al. 2008, 25-26; Stewart 2009). To date only one solitary and relatively minor conviction under the HAMP Act appears to have been made: in 2009 a jilted man was fined for slandering his ex-girlfriend as HIV positive (Kelola 2009). ${ }^{1}$ In the meantime, assaults, rapes and killings occur (including assaults, rapes and killings of people targeted because of some association with HIV), the majority probably with no reference to or consequence from any state law in PNG.

Several chapters have also highlighted the geographically limited reach of the state and the limited capacity of state agencies, even within their zones of operation (e.g. Patrick this volume; McLeod and Macintyre this volume; Dinnen and Law this volume; Hammar this volume; Haley this volume; Luker and Monsell-Davis this volume). The most publicised cases of civic insecurity involving criminal abuse and HIV unsurprisingly have happened near administrative centres, where the chances that these deeds will be heard about, seen and reported are greater. Joan's story of abuse and rejection unfolded within and on the edges of Goroka, the capital of the Eastern Highlands Province. Two other stories from the capital of the Western Highlands Province, Mount Hagen, retold from press accounts (see Boxes 1 \& 2) also suggest the relatively small and inactive part of state law, its machinery and enforcers in these ordeals.

1 To say this is a 'relatively' minor charge does not deny its seriousness, or that serious consequences can follow from such slanders. 


\section{Box 1}

The Hagen 'Lass'

On 6th January 2009, at about 2 am, a truck, laden with firewood and used truck tyres, drove into Kerebug Dump in Mt Hagen. Suspects laid out the tyres and firewood, placed a young woman-naked, blindfolded, gagged, and strapped to a log-on top, poured on petrol and set the pile alight (Muri 2009a). According to a witness, the girl could not cry for help. She was said to have HIV and to be a witch. Several days later, two different groups, insisting that she was two different people, claimed her body. A police officer explained to the press that establishing the girl's identity was hard, for unfortunately incidents such as these were not uncommon. The Director of the National AIDS Council Secretariat was reported to say, 'If anyone is caught and found guilty of burning the woman in Mt Hagen they can be prosecuted under the AIDS Prevention Act [sic] of 2003' (Noho 2009).

\section{Box 2}

\section{Rose}

On the eve of 2007 general election, Rose Kombe, then 16, was dragged from Mt Hagen and raped several times. Her attacker released her the following day. Considerably later an AIDS counsellor heard Rose's attacker boasting to some men that he had spread the virus to several 'young virgins' and mentioned Rose's name. The AIDS counsellor contacted Rose, who was now sick, and suggested that she take a blood test, which proved positive. This was a blow to her family, because young girls are 'precious' in the Highlands. Her family wanted to keep her, but because the community that hosted them (Rose and her family were immigrants) feared AIDS, Rose moved into a house in Mt Hagen for people living with HIV (Muri 2009c).

In September 2009, Rose was raped again. A grade 11 student, son of a prominent Hagen family, broke into the house. He was drunk and demanded sex. She warned him she was HIV positive and not to have sex with her. He punched her. She then offered him condoms which he threw away before he raped her. The landlord, on hearing her screams, was able to alert police, who arrested the young man. But charges were dropped when the PLHIVs received K1150 from the boy's mother (they had initially asked for K2000). When asked why she accepted compensation, Rose reportedly explained, 'Because we didn't want the young boy to go through a lot of trauma and agony. He knew very well that he had sex with an AIDS victim and that this memory will psychologically kill his mind if he was going to jail' (Anon. 2009b). Rose later told the paper that she and the other girls were subject to frequent attacks and rapes at the house. They wished it could be fenced: 'This place has got no fencing. That is why men enter the area at will and force us to have sex with them' (Muri 2009). NACS warned the public to refrain from this abuse of people living with HIV and said that NACS would pursue the matter under the HIV/AIDS Management and Prevention Act (Gerawa 2009). 
Partly in recognition of the state's shortcomings, increasing attention has focused on the potentials of community to ensure the safety of its members. In this volume, Reid has argued for 'community conversations' as a way for people to identify the challenges that they collectively face, understand the role of deeper structures particularly with respect to HIV and violence, and realise what they need to think and do for their shared future (Reid this volume; see also Gibbs 2009). The Tingim Laip ('Think about Life') project, the national HIV intervention program that commenced in 2005 and targeted 34 high-risk settings in PNG, has focused on building and mobilising communities (Katz et al. 2007; Engels 2008). In the law and justice sector, recent initiatives in community policing and the village court system have reinvigorated efforts to enlist and support local resources - and also strengthen connections between community and state (PNG 2007, 19, 35; cf. MacDonald 2008). More broadly PNG's government and development partners have directed policy and resources towards new paradigms for 'community-centric' development (Jacka 2007; Kidu 2008; James et al. 2009). Many of these draw inspiration from existing examples of successful grass-roots creativity (Jacka 2007; Wai and Maia this volume). Attempts have been made to theorise a new national and democratic civics rooted in the politics of kin (Goudsmit 2008). Others call for the forging of links between understandings of HIV, citizenship, and community responsibility (Aggleton et al. 2008, 22).

Therefore the thesis, articulated by Aral and her coauthors, that forms of community governance in primarily fostering civic security can also foster health warrant some further final thought (Aral et al. 2002; Luker and Dinnen this volume, chapter one). They specifically argued that the Zwelethemba model for community governance, while preventing community conflict and promoting cohesion, could be predicted to limit the spread and ameliorate the effects of STIs such as HIV. Without recapitulating at length the earlier discussions (Luker and Dinnen this volume, chapter one; Dinnen this volume, chapter 12; Cartwright et al. this volume, chapter 12), the model can be said (even if its proponents do not use quite these words) to work on two levels of prevention against conflict and HIV: one deliberate and closer to the 'surface', the other incidental and 'deep'. The deliberate peace-making prescribed by the model prevents minor conflicts from escalating. Under the model's design, the monies earned by peace-making not only personally remunerate individuals who participate, but a proportion of the small financial dividend goes to a fund that the community can spend on specific projects - including, if the community decides so, initiatives in health. At this level of prevention, problems are self-consciously identified and deliberately 'nipped in the bud'. At a deeper, unconscious level, the social cohesion created, collective knowledge articulated, conflict prevented, resources acquired, and the direction of these resources and human energy into other goal-oriented occupations for collective and individual 
benefit, may prevent some types of conflict and harmful behaviour before they have even 'seeded'. People, in effect, are otherwise engaged. It should be stressed that this model (like the kinds of community governance propounded by Goudsmit (2008)) explicitly links peace-making to tangible material rewards and real opportunities for locally formulated development projects: the personal remuneration for participants and the monies paid to the community fund are clearly incentives for individual and collective participation in the virtuous circle of the Zwelethemba process. Although the role for the state is limited, it is clearly defined and there is scope for its strategic enhancement.

This rosy picture at first glance 'makes sense'. Speaking loosely and generally, and without limiting the discussion to the community level of governance, the thesis that security - if defined as a condition of shared existence in which individuals can live with a high degree of confidence in peace, collective respect for cardinal social norms, and freedom from violence-seems logical. Conversely, the harmful effects of insecurity on health can be plain: witness deaths, sickness and social breakdown due to war. It is also easy to imagine a range of possible health benefits that might derive from enhanced security for any society - for example, lower morbidity and mortality due to injury; lesser costs associated with injury and traumatic death; better access to health services unimpeded by ambient violence; better health services because work-places are safe for staff; better health services because levels of internal corruption are low; and so on. The prevention of gender violence should also reduce, for instance, HIV transmission through violent or coerced sex as Eves argues (this volume), acknowledging the large international literature on this nexus. And despite the specific focus of Aral and her coauthors (2002) on the potential benefits of the Zwelethemba model for HIV prevention, the model is implicated in a body of work that more generally explores the potentially beneficial impacts of security on health (see e.g. Burris 2006). There is also a considerable literature postulating that measures primarily to foster health can also secondarily foster security, build peace, and legitimate states (Grove and Zwi 2009; Eldon et al. 2008; Zwi 2004).

But shadows cross this picture. Perhaps counter-intuitively, there are many examples of conditions of insecurity that correlate with health, and conditions of security with ill-health. For instance, the endemic warfare in precolonial Papua New Guinea may have helped to create cordons sanitaires that impeded the transmission of infectious disease and contributed to the health of populations (Denoon 1989, 9-17). Conversely, the peace that typically followed the introduction of colonial rule coincided with the spread of diseases and the very steep demographic declines of some societies in PNG and elsewhere in the Pacific (Luker 2008, 254-257). Certain work on HIV in Africa has also challenged assumptions that war or even rape necessarily spread HIV or correlate with high 
HIV prevalence (Whiteside et al. 2006, 212-214; Anema et al. 2008). The point to stress is that processes outlined in models are abstracted from the many processes with which they would interact in real life. Specific health data relating to the health effects of the Zwelethmeba model in the communities where it operates are also lacking. Burris, while insisting that the model indeed delivers health benefits, notes that these effects would anyway be hard to measure (Burris 2006, 210).

There are other shadows too. Many donors and governments that partner communities in projects of local governance subscribe to a set of Western democratic ideals and the principles of human rights. Yet these ideals and principles may not always neatly accord with local values. The village court system in PNG for example has been vigorously criticised by some commentators for judgements inconsistent with human rights or PNG's state law, but which arguably reflect local sociality and concepts of justice (Garap 2000; Goddard 2009, 13; cf. McLeod and Macintyre this volume). Contrasts are moreover often popularly drawn between grassroots moralities that prioritise 'community' versus a type of globalised morality that highlights 'the individual'; one that emphasises 'responsibilities' versus another that stresses 'rights'; one that supremely honours 'reproductive sexuality' versus one that, if not celebrates, at least forefronts 'non-reproductive sexuality'. These contrasting tendencies can sometimes correspond to differing conditions for social survival. In many communities in the world residents would depend for survival more on local politics, close cooperation among neighbours and the production of children than, for instance, do residents of the Canberra suburb where I live.

These contrasting tendencies can open up further differences-and those concerning roles and ideals for women are particularly raw. Women's heavy contribution in most PNG societies to child-bearing, production and service to others can often seem to their menfolk right and necessary. Without denying varied and changing views, many women agree and find their sense of selfworth and social influence in the hard work of motherhood and its associated roles (see, e.g., Sepoe 2000, 160). ${ }^{2}$ Differing measures for the scope of legitimate violence are also implicated. Although major donors may be based in countries where popular culture is saturated with commodified representations of violence and where governments exercise blood-spilling military might, salient Western attitudes allow much smaller scope for legitimate violence in every

\footnotetext{
2 It is worth noting that the mistreatment of women like Joan, the 'Hagen lass' and Rose easily yields to a kind of gender analysis in which they can be taken as embodiments of the multiple disadvantages that women can suffer in PNG. Following from such analyses, it may often be assumed that if women were given more power in political decision-making, such mistreatment would be challenged. While there is clearly a need for women to participate in formal decision-making from the local to the national level (see, e.g. Sepoe 2000; Sepoe 2007; Kidu 2009), subscription to the cluster of female ideals that centre on the maternal role seems to make many women very critical of others perceived to be anomalous.
} 
day and domestic life than accepted in some PNG contexts (see, e.g., McLeod and Macintyre this volume). As Michael Goddard has noted, a Western ethos that values social harmony, and sees it as necessary for community life, may actually be predicated on the experience of frail social bonds, so that some of those who subscribe to the 'harmony ethos' often have difficulty appreciating how stronger community ties may enable, ideologically and in practice, the accommodation and legitimation of violent acts that would permanently rend weaker communities (Goddard 2009, 4). Of course, as with the comments concerning women's roles, in PNG attitudes understood as 'traditional' with respect to violence differ, while modes of violence and associated perceptions are also changing, particularly where communities can no longer cope (see, e.g., Haley this volume). ${ }^{3}$ Finally, these contrasting tendencies, at the utmost opposition between the rights of the community versus the rights of the individual, can clash over the belief that, in the interests of the collectivity, a member or members can be disowned, discarded, or killed.

Divergent discourses about HIV draw attention to such contrasts and differences. Some, particularly over the supposed interests of the social collectivity versus those of the individual, have wrestled within Western HIV discourse from its early days (see, e.g. Scheper-Hughes 1994; Thôrn and Follér 2008, 282-283), notwithstanding the global ascendancy of the rights-based approach and forceful arguments that in fact it serves the interests of both. But Joan's story, and accounts of 'the Hagen lass' and Rose (Box 1), appear to exemplify the plight of individuals who are pushed outside the pale of social safety seemingly created by those values at the 'community' end of the series of popular contrasts outlined above, and often through acts perpetrated on their persons over which they had no control. Their membership of the group, and entitlement to its protection, were not inalienable but conditional. Their civic insecurity suggests the risk that new institutions of community governance might authorise the very values, or those people within the community who espouse them, that led to their mistreatment, rejection, and, in the case of 'the Hagen lass', murder. Indeed, despite examples of successful local governance, promising community conversations, and public education campaigns about human rights, some communities and spokespersons, in PNG and elsewhere, have called for stronger local powers to use means such as shame and expulsion to deal with the challenges of HIV and lawlessness, or for forms of 'guided democracy' out of temper with state principles or the democratic ideals upheld by key donors (see, e.g., Gigmai 2005).

3 The influence of Christian churches over the contrasting tendencies and tensions outlined in this discussion are often ambivalent. Some churches have locally strengthened the 'harmony ethos' (see, e.g. Goddard 2009, 6-7). On the other hand, most churches tend to endorse local values that centralise community and reproductive sexuality (see, e.g., Eves this volume). 
The greatest challenges for strengthening community governance pertain to those communities that need it most: 'intra-community', where members do not perceive a common interest with others in their midst, may feel poorly connected to neighbours by kin and culture, or would be difficult to draw into a common process with any available carrots or sticks; and 'inter-community', where a strong sense of community identity and cohesion can often be generated by conflict. In such settings the roles played by potentially a range of community actors and bridging agents, including representatives of the state, can be crucial in local political transformation. But it is also worth thinking about tangible 'peace dividends'. In the Zwelethemba model, money earned through peacemaking activities is a vital element; some recent recommendations for local governance in PNG similarly stress the importance of a real 'peace dividend' (Goudsmit 2008); and as Dinnen and Braithwaite have noted (2009, 165-167, 169-170), colonially the system of mobile colonial officers or kiaps, dovetailed the administration of justice with the rewards of local development projects. Yet one could ask: in some communities, would the possibly small pickings from peace-making activities or the prospect, for instance, of a functioning health clinic motivate those members who might want much more excitement or profit from criminal activities? Would the continuing pursuit of intergroup conflict offer key participants richer satisfactions than peace? Could a community deal with members beholden to powerful, translocal criminal organisations?

And civic security has macro-economic dimensions. This book has stressed that uneven development in PNG is a driver of many law and order problems and also HIV (Luker with Monsell-Davis, this volume). Competition for resources is a factor in inter- and intra-group conflicts; unemployment is a factor in property crime; labour migration is a factor in the spread of HIV; and so is the commodification of female sexuality that in turn responds to the pressing need for finding ways and means of tapping the cash economy. As Hammar's chapter (this volume) abundantly demonstrated, one cannot reduce 'transactional sex' to the narrow profile of a 'sex worker': it is a big and internally diverse category that can encompass bride-price and plet kaikai (sex for a plate of takeaway food), brief and long-term relations, reproductive and non-reproductive sex, the coercion of girls and women and, within the often severe limits on their life-choices, their agency. ${ }^{4}$ While much attention focuses on 'sex work' more narrowly defined and on the undoubted role that sexual violence can play directly and indirectly in the transmission of HIV, the array of economic pressures for and mulitifarious character of transactional sex is often more difficult to comprehend (see Epstein

4 The push factors for the commodification of female sexuality are richly illustrated in the disturbing 2005 report by HELP on the sexual abuse and commercial sexual exploitation of children (2005, see esp. 88-93); The monetary value that girls represent, through bride-price, is implied in the newspaper reports regarding the shock of Rose's family (Box 1) to learn that she had been raped, because girls in the Highlands are 'precious'. The subtext here is that her rape discounted the value she could command for bride-price. 
2007, 244-247; Barnett 2008, 8; see Luker with Monsell-Davis this volume). Thus the interests of civic security, not least with respect to HIV, property crime and violent competition for resources, are enmeshed in patterns of macrodevelopment over which institutions of community governance may have very little influence indeed.

Given the profound character of these concerns and others not flagged, is the goal of civic security worth pursuing? The obvious answer is: of course. As Anne Brown has remarked, 'The safety and relationships of trust that security implies are fundamental to good development, as they are to all forms of community well-being' (Brown 2007, 1). And despite the multiple actors that may be involved in its governance, the role of the state in realizing this public good is, in the words of Loader and Walker, both 'necessary and virtuous' (Loader and Walker 2006, 167). While PNG's young state has very limited capacity to ensure the security of its citizens through the arms of the law and its other agencies, it does have a cardinal responsibility to foster it.

Yet the special emphasis in this volume on the local governance of security is warranted: it is an inevitable consequence of the social realities in which most citizens live - as numerous community leaders, development practitioners, policy-makers, parliamentarians and social researchers have insisted. Strengthening the local governance of security involves mobilising resources at hand and also tapping resources from further afield (cf. MacDonald 2008). A range of local actors can contribute to these tasks, but state representatives, even if they are few and constrained, can potentially play vital roles in enabling and sustaining, bridging and channelling. As suggested in chapter one, perhaps too much talk of failed, fragile or failing states has muffled the possibilities of an 'enabling state'.

What would the 'civic security' resulting from such processes of localised political evolution look like? The question reminds us that any outcomes involving multiple sites, shifting circumstances, changing thought-worlds, and the mixing of endogenous and exogenous elements will be impossible to predict in detail; and it is hard to imagine that local, community politics in PNG could be otherwise. Various words - syncretism, fusion, hybridity, indigenisation-can denote ways in which local and more recently imported concepts and practices combine. Some of these terms have been applied to the adoption of Christianity in PNG and elsewhere. Political orders fashioned from local and translocal, indigenous and exotic elements in nations where state capacity is limited have also been described as 'hybrid'. These hybrid modes of governance, as Boege and his coauthors argue, can work, citing Bougainville as one example (e.g. Boege et al. 2008). 
Such processes however pose difficulties for purists, even when there is no alternative. Goddard addresses this in relation to PNG's village court system, which could be described as a 'hybrid' institution: though judgements may not always chime with state law or global rights discourse (and these discrepancies, particularly regarding women, can be abysmal (see, e.g. Garap 2000, 162-168)), he argues that village courts have by and large delivered 'substantial justice' in the estimation of their communities, women included, and have met a need (Goddard 2009, 13). The system moreover is evolving (Goddard 2009, 277-279). Reid (this volume, chapter 13) suggests other ways for working towards human rights in the prevention of violence and HIV. Like others (e.g. Cartwright et al. this volume, Barnett 2008), she puts heavy stress on looking ahead, on hope. Community conversations are a means of learning for change that is geared to the future: it is in the light of the good to which participants collectively aspire that current practices and values are reviewed. In this methodology, an impulse towards human rights serves, not condemnation, but local motivation to move forward. And many facilitators have noted that an appeal to the future of the clan, the lain, the community is in many settings a more effective motivator than an appeal to the individual, so sharply etched in the Western consciousness of human rights (see, e.g., Regan 2004; Kelly et al. 2008, 10; cf. Lepani 2007).

Nor are these processes for the impatient. HIV and 'law and order' pose challenges in PNG that are long-term, entwined and endemic: in important respects, as discussed in chapter one, common connotations of the term 'epidemic' and its related rhetoric are misleading when applied to HIV and, metaphorically, such problems as crime. In the absence of quick fixes, these require longer term thinking, which in turn require a broader and deeper consideration of context: not just to create social and political environments which 'enable' deliberate responses to HIV and 'law and order', but which are simply, inherently, safer. 'Civic security', as an ideal, encompasses these goods.

\section{References}

Aggleton, Peter and Shaline Bharat, Felecia Dobunaba, Roger Drew and Steve Wignall. 2008. Independent Review Group on HIV/AIDS: Report from an Assessment Visit 27 August-9 September 2008.

Aggleton, Peter and Shaline Bharat, Alex Coutinho, Felecia Dobunaba, Roger Drew and Tobi Saidel. 2009. Independent Review Group on HIV/AIDS: Report from an Assessment Visit 23 April-9 May 2009.

Anema, Aranka, Michel R. Joffres, Edward Mills, Paul B. Spiegel. 2008. Widespread Rape does not Directly Appear to Increase the Overall HIV 
Prevalence in Conflict-affected Countries: Now so What? Emerging Themes in Epidemiology 5 (11), http://www.ncbi.nlm.nih.gov/pmc/articles/ PMC2527307/ (accessed 27 April 2010).

Anon. 2009a. New Law to Curb Sorcery Killings. Post-Courier, 9 January 2009.

Anon. 2009b. Battle for Sorcery Killings. Post-Courier, 7 April 2009.

Anon. 2009c. Rapist Pays Price. Post-Courier, 1 September 2009.

Barnett, Tony. 2008. Hoping or Discounting the Future: A New Perspective on the Transmission of HIV/AIDS. World Institute for Development Economic Research, WDP 2008/08. Helsinki: United National University.

Boege, Volker, Anne Brown, Kevin Clements and Anna Nolan. 2008. On Hybrid Political Orders and Emerging States: State Formation in the Context of Fragility. Berghof Research Center for Constructive Conflict Management. [no place of publication given] www.berghof-handbook.net

Brown, M. Anne. 2007. Security and Development: Conflict and Resilience in the Pacific Islands Region. In Security in the Pacific islands: Social Resilience in Emerging States, ed. M. Anne Brown, 1-32. London and Boulder: Lynne Rienner Publishers.

Burris, Scott. 2006. From Security to Health. In Democracy, Society and the Governance of Security, ed. Jennifer Wood and Benoît Dupont, 196-216. Cambridge: Cambridge University Press.

CAP (Commission on AIDS in the Pacific). 2009. Turning the Tide: An OPEN Strategy for a Response to AIDS in the Pacific. Suva: Commission on AIDS in the Pacific.

Denoon, Donald. 1989. Public Health in Papua New Guinea: Medical Possibility and Social Constraint, 1884-1984. New York: Cambridge University Press.

Dinnen, Sinclair and John Braithwaite. 2009. Reinventing Policing through the Colonial Kiap. Policing and Society, 19 (2): 161-173..

Eldon, Jack, Catriona Waddington and Yasmin Hadi. 2008. Health System Reconstruction: Can it Contribute to State-building? London: HLSP Institute.

Engels, John. 2008. Tingim Laip: Success Stories from New Guinea. Waigani: Family Health International.

Epstein, Helen. 2007. The Invisible Cure: Why We are Losing the Fight against AIDS in Africa. New York: Picador. 
Garap, Sarah. 2000. Struggles of Women and Girls. In Reflections on Violence in Melanesia, ed. Sinclair Dinnen and Allison Ley, 159-171. Leichardt and Canberra: Hawkins Press and Asia Pacific Press.

Gerawa, Maureen. 2009. NACS Upset on Rape. Post-Courier, 8 September 2009.

Gibbs, Philip. 2009. Making Sense of HIV and AIDS: Community Conversations in the Papua New Guinea Context, in AIDS; Belief and Culture in Papua New Guinea, ed. Hermann Springler, special issue of Catalyst: Social Pastoral Journal for Melanesia, 39 (2): 56-70.

Gigmai, Freddy. 2005. AIDS Warning: Highlands Leaders Call for Condom, Nightclub Ban. The National, 21 November 2005.

Goudsmit, Into A. 2008. Nation Building in Papua New Guinea: A Local Alternative. State, Society and Governance in Melanesia Project Discussion Paper 2008/9. Canberra: State Society and Governance in Melanesia Project, Research School of Pacific and Asian History, Australian National University.

Grove, Natalie J. and Anthony B. Zwi. 2009. Beyond the Log Frame: A New Tool for Examining Health and Peace-Building Initiatives. Development in Practice 18 (1): $66-81$.

HELP. 2005. A Situations Analysis of Child Sexual Abuse and the Commercial Sexual Exploitation of Children in Papua New Guinea. Prepared by HELP Resources, Inc. with the support of UNICEF PNG.

Jacka, Marion. 2007. Local Solutions: Security and Development in Papua New Guinea. In Security in the Pacific islands: Social Resilience in Emerging States, ed. M. Anne Brown, 33-64. London and Boulder: Lynne Rienner Publishers.

James, Paul, Victoria Stead, Yaso Nadarajah, Karen Haive. 2009. Introduction: Projecting Community Life. In Projecting Community Life, by Paul James et al., Local Global: Identity, Security, Community 5: 6-16.

Katz, Che, Lesley Bola, Florence Bundu, Caroline Bunemiga B. Bus, Berit Gustafsson, Nayer Kaviani, Deborah McSmith, Romanus Pakure and Darryle Raka. 2007. Putting the Community at the Center of Measuring Change in HIV Prevention in Papua New Guinea: The Tingim Laip (Think of Life) Mobilisation. Health Promotion in the Pacific 14 (2): 133-138.

Kelola, Todagia. 2009. Hefty Penalty. Post-Courier, 26 May 2009.

Kelly, Angela, Frances Akuani, Barbara Kepa, Lawrencia Pirpir, Agnes Mek, Martha Kupul, Rebecca Emori, Somu Nosi, Lucy Walizopa, Brneda Cangah, 
Kritoe Keleba. 2008. Young People's Attitudes towards Sex and HIV in the Eastern Highlands of Papua New Guinea. Monograph 1/2008. Sydney: National Centre for HIV Social Research.

Kidu, Carol, 2008. The Power of Partnerships: Reflections on Addressing PNG Social Challenges. Presentation to the Lowy Institute, Sydney, 7 May 2008. Available http://lowyinstitute. org/ (accessed 27 April 2010).

Kidu, Carol. 2009. Rhetoric to Reality: Trying to Break the Gender Barrier in Papua New Guinea. The Parliamentarian 90 (3): 222-225.

Kirby, Michael. 2009. Foreword. In Criminal Transmission of HIV: A Guide for Legal Practitioners in New South Wales - May 2009, by Gina Mitchell, 5-6. Sydney: HIV/AIDS Legal Centre Inc. and DLA Philips Fox.

Lepani, Katherine. 2007. 'In the Process of Knowing': Making Sense of HIV and AIDS in the Trobriand Islands of Papua New Guinea. PhD thesis. Canberra: Australian National University.

Loader, Ian and Neil Walker. 2006. Necessary Virtues: The Legitimate Place of the State in the Production of Security. In Democracy, Society and the Governance of Security, ed. Jennifer Wood and Benoît Dupont. 165-195. Cambridge: Cambridge University Press.

Luker, Vicki. 2008. Papua New Guinea: Epidemiological Transition, Public Health and the Pacific. In Public Health in Asia and the Pacific: Historical and Comparative Perspectives, ed. Milton J. Lewis and Kerrie L. MacPherson, 250-275. Abingdon: Routledge.

MacDonald, Rosita. 2008. Safety, Security, and Accessible Justice: Participatory Approaches to Law and Justice in Papua New Guinea. Pacific Islands Policy No. 3. East West Center. Honolulu: University of Hawai'i.

McLeod, Abby. 2007. Police Reform in Papua New Guinea. In Security in the Pacific islands: Social Resilience in Emerging States, ed. M. Anne Brown, 7388. London and Boulder: Lynne Rienner Publishers.

Muri, David. 2009a. Hagen Girl Tied, Burnt to Death. Post-Courier, 7 January 2009.

Muri, David. 2009b. HIV+ Plea: Protect Us. Post-Courier, 4 September 2009.

Muri, David. 2009b. PLWHA Contracted Virus through Rape. Post-Courier, 8 September 2009.

Noho, Bola. 2009. Don't Hate HIV Victims: Pakure. Post-Courier, 12 January 2009. 
Papik, John. 2010. PNG Civil Groups Prepare Gay, Sex Work Law Challenge. Pacific Beat, Radio National, Australian Broadcasting Commission. 29 January 2010.

PNG (Papua New Guinea) 2007. A Just, Safe and Secure Society: A White Paper on Law and Justice in Papua New Guinea. Port Moresby: Office of the Secretary for Justice and Attorney General.

Poiya, Johnny. 2009. Woman's Body yet to be Identified. Post Courier, 20 January 2009.

Regan, Mary Walta. 2004. Report on Youth to Youth Theatre Troupe - Action for Change-Bougainville-Papua New Guinea. Caritas Australia with assistance of New Zealand Government AID.

Scheper-Hughes, Nancy. 1994. An Essay: 'AIDS and the Social Body.' Social Science and Medicine 39 (7): 991-1003.

Sepoe, Orovu. 2000. Changing Gender Relations in Papua New Guinea: The Role of Women's Organisations. New Delhi: UBS Publishers' Distributors Limited.

Sepoe, Orovu. 2007. Power, Gender and Security in Papua New Guinea. In Security in the Pacific islands: Social Resilience in Emerging States, ed. M. Anne Brown, 65-72. London and Boulder: Lynne Rienner Publishers.

Stewart, Christine. 2009. Posting on AIDSTOK listserve. 3 September 2009.

Thörn, Håkan and Maj Lis Follér. 2008. Governing AIDS: Globalization, the State and Civil Society. In The Politics of AIDS: Globalization, the State and Civil Society, ed. Håkan Thörn, and Maj Lis Follér, 277-296. Houndmills: Palgrave MacMillan.

UNAIDS. 2009. AIDS Epidemic Update: December 2009. Geneva: UNAIDS.

Whiteside, Alan, Alex De Waal and Tsadkan Gebre-Tensae. 2006. AIDS, Security and the Military in Africa: A Sober Appraisal. African Affairs 105/419: 201218.

Zwi, Anthony 2004. Health and Peace-building: Securing the Future. The University of New South Wales Health and Conflict Initiative Issues No. 1. Sydney: School of Public Health and Community Medicine, University of New South Wales. 